\title{
National Standards and Curricular Initiatives for K-12 Physical Education in the United States ${ }^{1}$
}

\author{
Prof. Dr.Mary O’Sullivan \\ The Ohio State University \\ USA
}

1 Paper to be presented at the International Conference for the 20th Anniversary of the Japanese Society of Sport Education, 17-19 November 2000, Osaka, Japan.

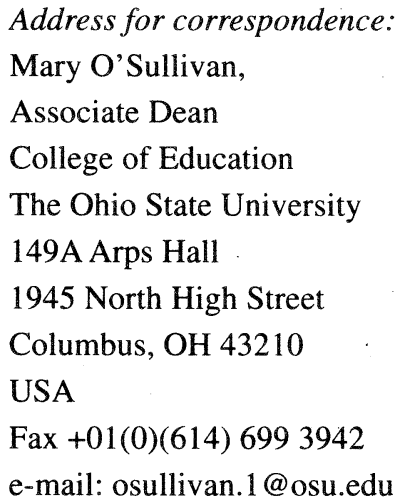

アメリカでは、教育は州の所轄事項であり、国家が関与するものではない。そのため、アメリカ全土で 拘束力をもつカリキュラムは存在しない。また、国家レベルでの目標に体育に関する記述はみられない。 州レベルでみても、時間数と一般的な内容の指針以外には、体育は何らの制約も受けていない。このよう な状況の中で、現実には体育の授業の调落現象がみられる。

そのため、状況を改善すべく、1992年にはNASPEが「身体的な教養を備えた人物」像を提案したり、1995 年に体育の授業の内容に関する全国レベルの基準を提案するといった努力が重ねられてきている。それら は、社会的に支持されるようになっている。また、スポーツ教育や戦術学習、責任ベース、フィットネス 志向等、複数のカリキュラムモデルが提案されている。

確かに、文化性を強調した論議は必要であるし、個人的にもその必要性を認識している。しかし、現時 点では、子どもや若者の健康を前面に押し出した論議を展開していくことが、体育の将来にとって好まし いと言える。

\section{Introduction}

I am honored to have been invited to speak on the challenges and possibilities facing physical education as each of us are attempting to improve the status of physical education in our schools. I have been fortunate to gain my formal education in three different countries and appreciate how we can learn from each other and build on each other's ideas as we face internal challenges to education and physical education. I received my undergraduate educa- 


\section{スポーツ教育学研究 第 20 巻 第 2 号 平成 12 年 11 月}

tion in Ireland in PE and Social Studies, my masters degree in Western Canada, and my doctoral work in the United States. I hope what I share about the American system will inform your efforts. I plan to learn about your educational system and how it can inform our efforts in physical education in the United States.

\section{The American System}

There are certain characteristics of the American education system that must be explained so you can better understand the curricular and policy initiatives underway currently. Despite many efforts currently focused on improving the education of the nation's children many believe student achievement will not improve in any significant way until we implement policies that address poverty and provide better conditions for children and their families to live and learn. Education in America is a State not Federal responsibility. While we have a series of 8 National Goals (www.ed.gov) focussed on, among others, Literacy, Math, Science, and Graduation rates from high school, the percentage of federal funding for schools is quite small (8\%). Most schools are funded by their State legislature and from local property taxes which has caused severe disparities in school budgets within and across states. The School Curriculum is both a state and a local responsibility not a federal issue. We have no national curriculum for Physical Education. The biggest push for time in many school programs is for technology and literacy and working internships at the high school level. There is no mention of PE or health in the US national goals and little or no accountability for learning in PE in most states. This is beginning to change and I will speak to that a little later in this presentation.

Lets review the number of school districts in the US so that you can gain an appreciation for the scale of effort that would be needed to bring massive change to PE programs nationwide. We have 50 fairly autonomous states when it comes to the education of their citizens. Nationally we have 91,340 schools that are organized into 16,411 school districts catering to over 40 million children. Half the nation's school children are educated in the largest 100 school districts. While each state determines educational goals, each school district determines how to meet these expectations. Each school district designs its own program of study by subject matter and may or may not be required to follow a model program of study from the state level. PE is largely unregulated at the state level except for time and general content guidelines.

\section{Physical Education in The United States: Some Na- tional Trends}

As recently as 1992 the National Association for Sport and Physical Education's (NASPE), Outcomes Project resulted in the publication of a document that defined what it means to be a physically educated person. Five main foci were developed specifying that a physically educated person was one who:

HAS learned skills necessary to perform a variety of physical activities

IS physically fit

DOES participate regularly in physical activity KNOWS the implications of and the benefits from involvement in physical activities

VALUES physical activities and its contribution to a healthy lifestyle

In 1995 NASPE developed a set of national content standards for physical education. The seven content standards were designed to establish what a student should know and be able to do as a result of a quality physical education programs. The Content Standards for a Physically Educated Person are as follows:

1. Demonstrates Competency in many movement forms and proficiency in a few forms

2. Applies movement concepts and principles to the learning and development of motor skills

3. Exhibits a physically active lifestyle

4. Achieves and maintains a health enhancing level of physical fitness

5. Demonstrates responsible personal and social 
behavior in physical activity settings

6. Demonstrates understandings and respect for differences among people in physical activity settings

7. Understands that physical activity provides opportunities for enjoyment, challenge, self-expression, and social interaction.

A second goal of the Task Force was to establish teacher friendly guidelines for assessment of these content standards what would be consistent with instructionally integrated orientations for the role of assessment in the teaching learning process. Some example Performance Benchmarks, which describe behaviors that indicate progress toward a performance standard for each content standard have been developed. This has received a great deal of attention in recent years with a series of publications for teaching on authentic assessment measures for K-12 physical education.

\section{Access and Participation to School Physical Education}

Despite these laudable efforts, physical education in schools continues to decline. The following is a quick snap shot of PE nationally understanding there are significant across state variations

- Only 1 state in USA (Illinois) requires daily PE $\mathrm{K}-12$

- Three states (Washington, Illinois, and Alabama) requires daily $\mathrm{PE}(\mathrm{K}-8)$

- Only 55\% of students are enrolled in PE

- There has been a large decline in PE especially at the high school

- '91--- $41 \%$ of HS students in daily PE

- ' 99 -.- $29 \%$ of HS students in daily PE

- $20 \%$ of HS students are active in PE for 20 mins or more

- Classroom teachers teach most elementary level physical education with specialists at middle and high school

- Ohio's requirements for elementary PE are part of 200 mins @ week allocated for Art, Music and PE. The requirement is often violated without any accountability. Students in middle school are allotted 80 minutes a week and two semesters of PE at the high school. These guidelines are adhered to by most schools.

\section{Physical Education Programs and New Curricu- lum Models}

One can make some generalization about the content of physical education programs nationwide. They tend to have the following characteristics

\section{Middle and High School}

- Sport and team game focus

- Health Related Physical Fitness is of growing interest. For example the high school PE requirement in the state of Florida is a health related fitness curriculum

- Physical Activity Promotion programs have become to appear. The M-SPAN program out of San Diego state is a federally funded curriculum research project from the National Institute of Health (NIH)

- There is limited but growing student choice within the curriculum especially at the high school with some push for choice at the middle school level

- Too many short 7-9 lesson instructional units though Sport Education with $20+$ lesson units is making a substantial inroad in middle school and high school programs

- Adventure Education programs are beginning. We have two such programs at the elementary level in Columbus though they are more often as high school level

\section{Elementary School}

- Integrated curriculum efforts (w/literacy, math)

- Fundamental motor skill development...vs discreet games (problem with untrained teachers)

- The nationally funded SPARK and CATCH programs at the elementary level are focussed on physical activity promotion with some attention to skill development

Several new curriculum models have been devel- 
oped, researched, and disseminated to physical educators across the country. These include;

1. A Tactical Approach to Teaching Games by Professors Griffin, Mitchell, and Oslin focuses on students' skill and tactical development and cognitive decision making on how best to organize tactics during game play

2. The Physical Best Curriculum by AHHPERD is a health related fitness education program

3. Sport Education by Professor Siedentop (1995) is focused on developing students into competent (skill and tactical development), literate, and enthusiastic sportpersons.

4. Don Hellison's (1995) model of "Teaching Student Responsibility through Physical Education" uses physical activity to help students take responsibility for their own and others learning. The model is used especially by teachers in urban settings who are looking to help students better manage their behavior.

5. The federally funded SPARK and $C A T C H$ programs by Professors McKenzie and Sallis (1996) promote a health related physical education focused on promoting physical activity at the elementary level.

6. Finally Professor Corbin's "Fitness for Life" curriculum is a conceptual approach to fitness at the high school and has caught the attention of teachers focused on promoting physically active lifestyles among adolescent youth (Dale, Corbin, \& Cuddihy, 1998). There are others (Strand, Scantling, and Johnson, 1997) who have designed similar programs.

A myriad of curricula have been put forward for physical education teachers. There are other curricula such as Sport for Peace (Ennis, 1999) anda Cultural Studies Curriculum (Kinchin and O'Sullivan, 1999) but time does not allow for a discussion of these models.

\section{Challenges to Physical Education in the United States}

We have several challenges facing physical edu- cation in North America. We have a national obesity epidemic in America. "All indications are that the current generation of children will grow into the most obese generation of adults in US history" (Hill $\&$ Trowbridge, 1998). This comes as an annual cost to the nation of over 100 billion dollars. A key factor in obesity is lack of exercise. Almost $60 \%$ of the American adult population is sedentary and $25 \%$ of that group is totally sedentary. Some groups are more at risk for inactivity than others such as

- Women

- Lower income and less educated persons

- African Americans and Hispanics

- Female African American adolescents and

- People with Disabilities

There are significant concerns about adolescent who are overweight /obese

- In 1991, 4 States with $14 \%$ of children obese ('98 = 37)

- Percent $(11 \%)$ of overweight youth doubled in 30 years

- 6 million children are obese

- 1 in $4(25 \%)$ adolescents overweight/at risk

- White males (27\%) more than females (18\%)

- Black (36\%) \& Hispanic (28\%) females most at risk

- Type 2 diabetes now showing up in adolescents (CDC, 2000).

It should come as no surprise then that physical activity levels among the national adolescents are also dropping while other health risk behaviors (tobacco and alcohol are on the rise yet again).

- $11 \%$ drop in vigorous PA in 3 yrs (boys)

- $18 \%$ drop in vigorous PA in 3 yrs (girls)

- Only 55\% of student had played on sport teams: Boys (61\%) and Girls (48\%)

The determinants of exercise for youth are multi faceted and vary by age and gender in the US. We know that:

- Levels of physical activity decline dramatically during adolescents

- Children and adults from higher SES families are more active (i.e. access) 
- Social component is more important to 9 th grade girls than boys

- Parent's participation (father) is a key to child's participation

- Youth will play sports they enjoyed as children

- Barriers to participation (DiLorenzo et al., 1998) include time, facilities, safe spaces, transportation, and costs (rise in private sport clubs)

\section{Consensus on Physical Education Goals}

There is a lack of consensus about what should be focused on in the physical education curriculum. While we have a definition of a physically educated person and content standards related to this definition, few schools and programs have the time to address all these content standards adequately. Many physical educators are unclear which objectives to focus on in their program. Too many try to address them all and all too often fail to achieve any of the unrealistic expectations they have placed on themselves and their students (Payne,1998).

On the positive side, we have seen a shift away from a Medical 'dose-response' model with the FITT principles of health related fitness to a milder dose response that includes moderate activities that are part of every day life (walking and biking to school, raking the leaves etc.). There are others scholars who promote the inherent joy of physical activity. They argue we should seek better ways to allow students to enter sport and physical activity sub cultures. They are convinced that when students "enter the sub culture" they will find intrinsic meaning and relevance. This is the challenge to those of us in the sport pedagogy community.

\section{Advocacy for Physical Education?}

There are some societal pressures that promote physical education. Kurt Lewin in his explanation of how change takes place suggested that change was more a function of decreasing the barriers to change and less the magnitude of the forces for change. I conclude here by suggesting a series of "pressures" in American society that could help im- prove the status of Physical Education in schools and communities. These efforts will be successful depending on our ability to minimize the barriers that inhibit improvement. I will refer to this as the Competing Tensions Theory. There are several positive pressures in the USA that could allow PE to take a more prominent role in schools and in the education on our young people. These are:

- Legislative Actions

- National Reports

- Health Costs

- External Supports from prestigious agencies and persons

However, there are powerful inhibitors to changing the status quo also. These include time, facilities, professional development, societal values, and legislation

\section{Pressures and Resistance to Change}

Here are some of the positive pieces of National Legislation related to $\mathrm{PE}$

1. The Senate Resolution for Daily PE. passed the US Senate a decade ago though it has had little of no effect until now

2. The Physical Education Progress Bill (PEP) has been proposed in 2000 with a $\$ 400$ million budget for PE over 5 years to Initiate, Expand, and Improve PE programs for all K-12 students, Require at least 150 mins @ week in PE, and Fund equipment for quality programs www.aahperd.org/naspe/whatsnew-pep.html). This bill is currently on hold until congress resumes but the advocacy efforts of NASPE and AAHPERD have been significant and substantive with 19 Senators co-sponsoring the bill.

3. Americans with Disabilities Act (ADA) has focused attention on ensuring that all American and especially young Americans have equitable access to physical educational and physical activity spaces in school and community settings. There are strong legal statutes that parents can use to hold schools and communities accountable for such provisions. 


\section{スポーツ教育学研究 第 20 巻 第 2 号 平成 12 年 11 月}

4. The "Congressional Health and Behavior Caucus" had been established to highlight the role of behavior in health and promote research findings that promise to improve the health and quality of life for Americans.

Pressures to resist change include:

1. A decrease in some state level requirements for PE. For example the State of Massachusetts has left it to local school districts to determine if PE should be mandatory or not. Such a proposal was discussed in my own state but later dropped.

2. An increased focus on higher academic standards have placed tremendous stress on the school timetable and put PE on the back burner. In Ohio, PE teachers are often required to spend an hour or more a day tutoring elementary students in reading rather than teaching physical education.

Yet, some states, including South Carolina (SC), Washington, (WA), and New York (NY) have placed $\mathrm{PE}$ on the state report card: In these states PE teachers must report on how many of their students have achieved the performance benchmarks laid out by the state physical education curriculum. These efforts pave the way for major accountability measures for PE in schools in the years to come.

\section{National Reports}

Several national reports have focused attention on children's health and school physical education. The most significant of these are

- The Surgeon General's Report (1996) is the first of its kind at a national level to focus attention on physical activity. A similar report on tobacco 25 years ago was very influential in creating policies aimed at decreasing the numbers who smoked and limiting places that people could legally smoke. If we generate similar policies promoting physical activity then we have great opportunities to place physical education at the center of a child's education

- The "Healthy People 2010" report (www.health.gov/ healthypeople) advocates increased time and focus on physical education in schools with specific objectives promoting physical activity among youth. These are:

Slide Nineteen Objectives for Physical Activity Among Children and Adolescents

Baseline Goal

$22.6 \Uparrow \%$ engaged in moderate -vigorous Physical Activity over 5 of 7 days (walking, biking, game play, raking leaves)

$$
20 \% \quad 30 \%
$$

$22.7 \Uparrow \%$ engaged in vigorous Physical Activity 3 days@ week for 20 mins

$$
64 \% \quad 85 \%
$$

$22.8 \Uparrow \%$ of public $\&$ private schools that require daily PE

$$
\text { MS- } 2 \% \quad 5 \%
$$$$
\text { HS- } 17 \% \quad 25 \%
$$

$22.9 \Uparrow \%$ of adolescents who participate in daily PE

$27 \% \quad 50 \%$

$22.10 \Uparrow \%$ of adolescents who are active for $50 \%$ of PE class

$32 \% .50 \%$

$22.11 \Uparrow \%$ of adolescents who view TV less than 2 hours@week

$$
60 \% \quad 75 \%
$$

$22.12 \Uparrow \%$ of schools that allow access to facilities after school

None $75 \%$

- The CDC Guidelines to Promote Lifelong PA among Youth People presents 10 guidelines that address Physical Education, Health, Extracurricular Activities, Parental Involvement, Community programs, and the Environment (www.cdc.gov/nccdphp/dash/phactaag.htm).

- The California Healthy Schools Summit (2000) focused on healthy school environments with special attention on nutrition and physical activity

Yet, there are equally powerful counter arguments 
that resist change. These include the

poor academic achievements especially related to Literacy and Math, demand for more technological preparation of children for the information age, and the concerns about unsafe schools and communities

\section{Reasons for Optimism}

- There are some specific PE curricular initiatives that create reason for optimism about Physical Education in the USA at the beginning of the $21^{\text {st }}$ Century. Curricula have improved and several Curricular Models have been disseminated with varying degrees of success. In addition other efforts have helped to improve the status of PE such as:

- Sport for All is a NASPE initiative to increase Physical Activity \& positive social interactions among children \& youth. The Program is designed for elementary and middle schools, community and after school programs, and day care centers. Children ages 1-14 years are the focus. NASPE has collaborated Human Kinetics to best disseminate the materials.

- SPEAK II: Advocacy Kit for Sport and PE is a packet to help PE teachers advocate for PE in their school and community with parents and community leaders.

- The National Teaching Standards Boards now provides for PE teachers to gain national Certification. Most states and school districts provide bonuses of $\$ 2,000-\$ 4,000$ to base salary. These teachers can be either elementary or secondary teachers.

- Finally there is The American Master Teacher Program, a non profit professional development program for experienced elementary PE teachers to gain additional certification as a Master Teacher. It was established by George Graham and very well respected nationwide though the financial incentives are not in place.

\section{Conclusion}

There are many curricular, legislative, and state and federal initiatives that are coalescing around physical activity and children's well being. The degree to which we can predict whether the status of Physical Education in American schools can and will improve is depicted visually in this slide. There are several initiatives underway from both within and outside the profession to suggest PE will gain more respect in schools, offer better quality programs, and be held accountable for student learning. However, the reality of high stakes testing for a narrowly conceived set of academic experiences for children has a stranglehold on American education. Fore grounding children and youth's health using a public health agenda seems wise at this time. Later we can move to a more culturally relevant argument when PE is back in schools. Only time will tell if this is possible though I am more optimistic than I have been in recent years.

\section{References}

CDC (2000). Morbidity and Mortality Weekly Report 29, No. SS-5. (ftp://ftp.cdc.gov/pub/Publications/mmwr/ss/ss4905.pdf).

Centers for Disease Control and Prevention (1999). Youth Risk Behavior Survey (YRBS). Atlanta, GA: United States Department of Heath and Human Services:

Cowley, G. \& Begley, S. (2000). Generation XXL, Newsweek, July 3, 40-46

Dale D., Corbin C., \& Cuddihy, T. 1998. Can conceptual physical education promote physically active lifestyles? Pediatric Exercise Science, 10, 97 109.

DiLorenzo et al. (1998) Preventive Medicine, 27, 470-477

Dunn et al. (1999). Comparison of lifestyle and structured interventions to increase physical activity and cardio-respiratory fitness: a randomized trial. Journal of American Medical Association, 281, 327-334.

Ennis, C. (1999). Creating a Culturally Relevant Curriculum for Disengaged Girls. Sport, Education and Society, 4 (1), 31-39. 
Hellison, D. (1995). Teaching responsibility through physical education. Champaign: IL: Human Kinetics

Hill, J. \& Trowbridge, F. (1998). Childhood obesity: Future Direction and research priorities. $\mathrm{Pe}$ diatrics, 101, 3, 570.

Kinchin, G., \& O'Sullivan, M (1999). Making physical education meaningful for high school students. JOPERD, 70(5), 40-44,54.

National Association for Sport and Physical Education. Shape of the Nation Report: A Survey of State Physical Education Requirement. 1997. Reston, VA: AAHPERD. http://www.aahperd.org/ National Center for Health Statistics (2000). Fast
Stats A to Z. http://www.cdc.gov/nchs/fastats/htm (reviewed October 4, 2000).

National Vital Statistics Reports, Vol. 48, No. 11

Payne, G. (1998). Spring Cleaning. NASPE News, 50, Winter, pp. 2, 14.

Siedentop, D. (1994). Sport Education: Quality PE through positive sport experiences. Champaign, IL: Human Kinetics.

U.S. Department of Education (1998). National Center for Education Statistics. http://nces.ed.gov/ index.html (reviewed November 14, 2000)

U.S. Department of Health and Human Services (US DHHS). (1996). Physical Activity and Health: A Report of the Surgeon General. Atlanta, GA. 